\title{
Enhancing Literacy Concepts: Digital Natives and Cultural Tools
}

\author{
Marguerita Magennis \\ Portobello Institute; Dublin City University, Dublin, Ireland
}

\begin{abstract}
The paper reviews national and international literature on the effects of information and communications technology (ICT) in enhancing the conceptual development of children, and the impact of ICT in classrooms looking in particular at developing literacy skills in 0-3 years old children. Consideration is given to the effectiveness of computers and media equipment when integrated successfully, to enhance the holistic development of the child, while focusing on the area of literacy. This paper addresses the debate over the value and desirability of children in early years using computers; while considering the diversities involved with the use of ICT as opposed to traditional teaching methods in the area of developing concepts of early literacy, communication skills, and involvement. The paper links to a recent masters study which was completed in the area of pre-mathematical concepts, indicating significantly positive correlations for the implementation and use of ICT as a cultural tool to enhance the development of Irelands "digital natives" in preparation for a technologically changing society. The incentive for looking into this subject stems from the realisation that in spite of all the literature available on ICT and media in education, there is no real systematic discussion in the area of early years and pedagogy. This subject refers to what is suggested to be the most influential change in the educational system over the past decade, indicating a changing process which could not only determine the shape of educational systems, but also the nature of future generations and in fact education itself. This lack of discourse is proving detrimental to technologically changing societies and the complete understanding of what exactly is incorporated and involved in the term "integrating ICT and media" as a resource to enhance the early concepts of literacy. Research will be drawn from areas of literature, with supporting recommendations from Department of Education and Science (DES) (2011a; 2011b) and Punie, Zinnbauer, and Cabrera's (2008) A Review of the Impact of ICT on Learning, providing current policy evidence to support the implementation of ICT in the Irish education system. It is important to note that there is a lack of information and good quality research findings on ICT in educational settings and particularly in the area of early years and literacy development. Furthermore, reports, articles, and Websites claim great benefits derived for children using ICT; however, evidence-based research for such writing is weak and unsupported at times, resulting in a lack of understanding of the benefits and the need for early intervention in this area, if children are to progress and develop into socially competent adults in a world where ICT, media, and technology are becoming part of their daily existence. It is intended that this contribution will help overcome the current phobias which are often associated with ICT and young children, while introducing new ideas of how beneficial this resource could be if implemented in a supporting manner.
\end{abstract}

Keywords: digital technologies, digital natives, early education, pedagogies, statistics

Marguerita Magennis, Ph.D., senior lecturer, Department of Early Childhood Studies, Portobello Institute; lecturer, Department of Open Education, Humanities, Dublin City University. 


\section{Introduction}

This paper focuses on knowledge, learning, and information and communications technology (ICT) in early years education, concerned with the ways over views of ICT can shape the pedagogies in early education. The focus therefore requires deliberation of the ways in which ICT should be used to support teaching and enhance learning experiences of 0-8 years old children and in particular under three years old in early education, identifying new and dynamic methods now available in this technological era (Magennis, 2011). In this paper, consideration will be given to the effects of ICT in enhancing the conceptual development of children; the impact of ICT in the classroom with consideration given to the effectiveness of computers and media equipment when integrated successfully in enhancing the holistic development of children in the early years sector. The paper will address the debate over the value and desirability of children of this early age using and becoming involved with ICT, while considering the diversities involved with the use of ICT as opposed to traditional teaching methods in the area of developing concepts in early literacy, communication, and involvement. Supporting evidence shall be drawn from a recent master's study completed in the area of pre-mathematical concepts, indicating positive correlations for the implementation and use of ICT as a cultural tool to enhance the development of Ireland's "digital natives" in preparation for this technologically changing society.

\section{International Review}

Research into literature and practice on the provision of ICT and policy development in early education across the UK and Ireland quickly reveals ICT as being high on the list of priorities that policy-makers, educators, and parents have for education (Higgins, 2002), with the ever increasing widespread belief that children will need ICT if they are to survive in a world filled with technology (Magennis, 2011; Stephen, 2012). Furthermore, political commitment to the provision of suitable settings and conditions in which to develop a knowledge economy gives rise in school sectors to new initiatives, such as the National Grid for Learning and ICT training for teachers and early years practitioners (Magennis, 2011; Stephen, 2005; 2012).

Yelland (2010) specified the significance of preparing "citizens for tomorrow", claiming that teachers are often aggrieved over the lack of skills in spelling and handwriting, together with a distinct inability to recall. However, she highlighted the unmistakable silence concerning the range of new skills children will gain, for example, "multimedia text with content derived from a variety of sources, and thinking skills developed in multimodal formats" (Yelland, 2010). Importantly, Yelland believed that if ICT is to be pertinent to the lives of these "future citizens", education should cater for their diverse worlds and recognize that life has become increasingly complex; a fact which should be reflected in the changing curricula and more importantly in the early years sector, where such changes are often overlooked. Accordingly, it should be remembered that the old basis of reading, writing, and arithmetic, while remaining functionally relevant, has been supplemented by the need to be innovated and creative, taking into account changing societies. Therefore, when Yelland (2010) indicated the importance of knowing how to add and change, it is equally and arguably more important to know when to add and change. Consequently, new technologies are a vital part of this learning process, yet evidence suggests that within schools, they remain peripheral to the main subject area and in many ways are seen as "tokenistic", rewards as opposed to indispensable learning tools.

In 1996, Papert criticised policy-makers who were "determined to use computers but can only imagine them in the framework of a school system", in effect strengthening an already poor curriculum and method of 
education. In 2012, it would appear in many cases that things have not been changed (Magennis, 2011), supporting claims that the level of awareness among teachers, particularly in the early years sector, remains low, with fewer than half the respondents (in a recent study) at both primary and post-primary levels reporting an awareness of the need for ICT; the awareness was higher however among ICT co-ordinates than among other teachers (Department of Education and Science (DES), 2008a).

\section{Should Young Children Use ICT?}

There has been extensive research into computer-assisted instruction (CAI) and computer-based learning (CBL), with studies of Fletcher-Flynn and Gravatt (1995) identifying almost 400 reports which highlighted two main areas for query. Firstly, questioning the possibility that the impact of computers will increase further, and secondly, suggesting that ICT only produces relatively small improvements, with other types of educational interventions, peer tutoring, reciprocal teaching, and homework, producing greater than average impacts (Marzanos, 1998). British Educational Communications and Technology Agency (BECTA) (2008) however found no clear links between levels of resources for ICT, for either reading or mathematics at age 4-7 years in 1999; with findings showing a significant association between ICT researchers and pupil attainment between the ages of 7-10 years (Magennis, 2011). Studies in the US also found a small link between the use of computers in curricula areas and improvement in pupil attainment (Weaver, 2000; Magennis, 2011). While Gialamas and Nikolopoulou (2010) indicated the beneficial effects of using interactive teaching programs on pre-school children's literacy development, with results indicating a significant increase in word decoding, phonological awareness, and concepts of print, all of which are components of emergent literacy.

Since it is evident that this interest into ICT in early education stems from the increased desire to prepare children at an early age to succeed in an increasing complex and technological era, why in Ireland and parts of the UK is there still a refusal to take this on board. Despite ICT being seen by governments and colleges as potentially improving the quality of education and standard of teaching in everyday classrooms (Plowman \& Stephen, 2005), it would appear that this debate has become polarized between those highlighting computers as detrimental to health and learning and those supporting claims that ICT makes a key contribution to the holistic development of the "digital natives". Strongest evidence found in "Fool's Gold: A Critical Look at Computers in Childhood" (Alliance for Childhood, 2000) a conservative view, calling for the immediate cessation on the further introduction of computers in early years, with a notable exception for special needs and disability (Plowman, McPake, \& Stephen, 2008); leaving one to wonder why special needs with no awareness of the benefits to every child. Alliance for Childhood (2000) recommend a refocusing on the "essentials of books and the hands on experience of the natural world" (as cited in Plowman \& Stephen, 2003, p. 151); however, if the "natural world" has changed so much that books and hands-on experience are being replaced by "digital media" and ICT, should educators still be teaching using these primitive methods, or should education be looking at the "cultural changes" and applying them to the "cultural tools". Darwin talked of adaption of the species-How does society propose for these "digital natives" to evolve when educators continually restrict their access to the necessary materials to aid this progression? Buckingham (2000, p. 21) adopted the "death of childhood" perspective and found a consideration of panic and nostalgia, a position which is opposed by beliefs that children are in fact empowered by new media, such as ICT, which can inevitably be used creatively and is central to the encultinalization into a new knowledgeable society (Stephen, 2005). 
Literature shows that the predominant view among those who are critical of ICT being used in pre-school is that as a screen-based medium, activities at the computer are not as effective as manipulative or concrete activities in developing concepts and skills in early years (Yelland, 1999), particularly in areas of physical skills where computer use is not always developmentally appropriate (Haugland, 2000). This somewhat dated research has been contradicted with results from a recent study (Magennis, 2011), which shows positive correlation in computer-based activities as opposed to concrete activities. Perhaps there is a need to address issues such as provision and attempt to identify where the shortfalls lie, while further addressing the question of what exactly is meant by ICT, with most research looking specifically at computer-based activities.

\section{Provision in Pre-school}

According to Plowman, Stevenson, Stephen, and McPake's (2012) observation, computers are more often available during free play, with resent research revealing no statistical evidence about current usage (Plowman \& Stephen, 2005), pointing out that if a deficit model of training for practitioners is to be avoided, it is necessary to consider how capable children and adults currently are at using computers and ICT, suggesting that often parents display more enthusiasm than teachers, perhaps due to certain ambivalence about the value of ICT in the practice.

Haugland (1999), J. Siraj-Blatchford and I. Siraj-Blatchford (2002), and Plowman and Stephen (2003) suggested that teachers are struggling with questions of their role and find it difficult to incorporate ICT into the lesson, while in more recent research, Hermans, Tondeur, Ban Braak, and Vakke (2008), Vekiri (2009), and Gialamas and Nikolopoulou (2010) provided supporting evidence to suggest that teachers' beliefs impact upon their use of ICT in the classroom, with Vekiri (2009) highlighting the importance of pre-service, postgraduate, and continuing professional development (CPD) to ensure successful integration and retract from negative experiences for children, particularly very young children.

On a more positive note, Jordan (1999), Bolstad (2004), and Patterson (2004), as a result of case studies, indicated evidence in New Zealand of ICT use in early education becoming extremely common and beneficial; further supporting Downes (2002) reflecting an "ecological view" of children's use of ICT, while drawing mainly on factors in children's cultural and social lives, including language, gender, and economics and social status; supporting Stephen's (2005) identifying evidence highlighting the importance of the practitioners awareness of a child's social and cultural situation, if they are to meet the individual requirements of every child, a move forward from suggestions that technology should have a compensatory role, offering specific assistance to children from disadvantaged backgrounds only (Cohen, 1993).

\section{Effective Use of ICT: Potential Benefits}

Plowman et al. (2008) highlighted peer guidance as a distinct advantage to children; however, it was pointed out that no explicit learning was evident if a specific problem was encountered and the more competent children tended to provide instruction without explanation. Accordingly, Plowman and Stephen (2005) identified "reactive supervision" as the most common form of adult guidance, operating by default rather than pedagogical strategy.

Stephen and Plowman (2003) discussed the need for effective ICT in a classroom requiring new ways of thinking and incorporating ICT materials as a teaching tool, with further research in 2005 indicating the limits of simple drill and practice programmes, supporting earlier claims of Davis and Shade (1999) for the need for proper integration into teaching if ICT is to be effective, with Cooper and Brna (2002) highlighting the 
sensitive adult intervention. O'Hara (2004) made relevant links to cognitive theories of development, highlighting theories of Bruner and Vygotsky as beneficial in supporting the learning environment. Most recent research indicates the need for the child to have relevant, regular access if ICT is to be effective (Dawson, 2008; BECTA, 2008), identifying the shortfalls evident in Ireland, with the lack of access to up to date computers, ICT, and Internet being of major concern in most rural primary schools and early years settings, as evidenced in a recent study (Magennis, 2011).

Learning with ICT. Current views remain divided as to whether ICT enhances and facilitates the learning experience. Elkind (1996), Healy (1998), and O. Fomichova and V. Fomichova (2000) took a negative stance, pointing out ICT proficiency does not necessarily confirm cognitive development, suggesting computer interaction is best left to the older child; while Moseley et al. (2005), Stephen (2005), and BECTA (2008) indicated that ICT, when incorporated in the correct manner with a suitably trained adult, can enhance early years development, across a range of areas, supported by Magennis (2011). Plowman et al. (2012) indicated the benefits for children gaining an understanding of the world around them. Hohmann (1998) supported claims of benefits to young children using a computer mouse in the enhancement of motor skills, co-ordination, and manipulative skills, while Fatouros (1995) maintained ICT was beneficial in enhancing communication skills, social skills, turn taking, and collaborative problem-solving. However, Stephen, Plowman, and McPake (2010) and McGarr and Kearney (2011) indicated a significant lack of supporting evidence in the early education sector.

Impact. ICT can and should be integrated into the class situation providing benefits of one-to-one or as group support, although the effectiveness of each approach has been substantiated, the different approaches will undoubtedly influence the results. Higgins (2002) suggested that this variance is influenced by teacher interactions, while claims by McClain and Cobb (2001) propose that ICT in group situations will enhance thinking, understanding, and interaction across curriculum areas. Evidence supporting the positive influence of ICT can be found in studies including "mathematical thinking and problem-solving" (McClain \& Cobb, 2001), "individual reasoning" (Dawes, Mercer, \& Wegerif, 2000), "conceptual change in science" (Eidson \& Simmons, 1998), and "pre-mathematical concepts" (Magennis, 2011). Davis and Sullivan (2002) proposed that talking books had the potential to be beneficial in literacy development, if teachers and parents were willing to take on board a new diverse method of teaching; reinforced by further studies by Wood, Phillinger, and Jackson (2009) identifying four types of literacy intervention when using talking books to enhance reading skills. Later studies by Madden, Chung, and Dawson (2009) highlight the potential benefits of ICT as a cultural tool to enhance story boarding in early years, and also in the area of story writing in older children, with findings showing the benefits of considering new approaches to design story visualisation tools for young children.

Earlier studies of Talley, Lancy, and Lee (1997) and Plowman and Stephen (2003) offered opportunities for CD story books to be used with four years olds, resulting in evidence that CDs were a useful commodity for increased exposure to print, particularly advantageous when children's home situations limit access to books (Plowman \& Stephen, 2003; 2005; Plowman et al., 2012), with Hayden (1998) highlighting significant benefits when ICT was used in pre-school to support children with special educational needs. For example, the UCRA Intervention Program provided evidence of increased interaction, engagement, and social skills during computer activities (Howard, Dryden, \& Johnson, 1999; Stephen, 2005; 2012). Shamir, Korat, and Barbi (2008) in research into benefits of CD-ROM story books highlighted ICT as particularly important to nursery school 
children, concluding that paired peer learning in early childhood with a high quality e-book could support a variety of children's emergent literacy skills.

\section{Irish Context}

International literature suggests that changes are evident and are in some cases being effective with studies demonstrating positive effects on early education and media interaction for children. However, literature in Ireland in the early year sector is limited and the impact of ICT as a resource supporting these "digital natives" is understated.

Policy documents and legislation accept the need for ICT in Irish education. Organization for Economic Cooperation and Development (OECD) (2001) established a need, but indicated how, a lack of funding in this area leaves children with little or no access. Smart Schools: Smart Economy (DES, 2011a) provides a vision for digital learning with advisory groups visualising an education system that equips young people with limited skills for the 21 st century economy. However, very little evidence shows this vision actually being put into practice; while the DES (2011b) discussed raising awareness of promoting better understanding of the critical importance of supporting children's ability in areas of literacy and numeracy in all areas of communication and technology (2011-2020). However, with reduced funding available to already under resourced schools, the likelihood of achieving this aim is becoming less probable when children are suffering already from unsatisfactory educational facilities. The DES (2011b) aims to improve outcomes at early childhood level. However, despite research in this area, Punie, Zinnbauer, and Cabrera (2008) in A Review of Impact of ICT on Learning suggested changes in the areas of training and resources, with Helios (2006) arguing that access is limited and as e-learning develops further, consideration needs to address other concepts of ICT than just computer use and the involvement of home and school, i.e., Internet café, media, social networks, phones, etc..

Despite positive research in studies including O'Neill, Hayes, and Downey (2008), progress is increasingly slow. Siraj-Blatchford and Whitebread (2003) indicated the importance of a "technological literacy" within the early curriculum, while Freeman, Holmes, and Tangrey (2010) discussed issues of government investment as a suggested method of promoting ICT in the school system and a way of evaluating the use of ICT in the classroom, using findings to evaluate key themes and inform policy reform; thus influencing the use of ICT as a tool to reshape learning. However, in order to assess best practice and government policy, there is a need to provide evidence that policy is actually being implemented and if not why? Addressing the questions of what key components are missing?

McDermott (2011) identified the need for awareness of the practitioner's role if ICT is to be an effective tool, highlighting the shortfalls in training, $\mathrm{CPD}$, and resources available. While significant research in this field from McGarr (2009; 2010) indicates positive changes in some areas of post-primary education, examining the initiatives evident and policies apparent in the area, McDonagh and McGarr (2012) further indicated that although these changes are a positive move, predominantly the use of ICT lies within "discrete informatics"; subject areas which tend to concentrate mainly on learning about technology rather than learning with it. Furthermore, ICT policy needs to be conscious of the past, with particular emphasis on how national ICT initiatives are mediated within schools and the prevailing ICT culture (McGarr \& Kearney, 2011).

\section{European Commission Statistics}

The Educational Audio Visual and Cultural Executive Agency (EACEA) (2011) published statistics 
focusing on 27 European Union (EU) member states, three candidate countries, and numerous countries from the European Economic Area (p. iii) subsequently called EU+ countries; indicating 12 of the $38+$ countries were able to acknowledge their involvement in monitoring ICT indicators regularly at the level of primary and/or secondary education, Ireland was not among the 12; with 10 of the 12 countries indicating monitoring at both primary and secondary levels; while Austria and Norway indicated secondary only. Results indicated over $82 \%$ of panel member countries identifying pedagogical ICT competencies of teachers as an area in need of monitoring and improving, with teacher ability coming second at $65 \%$. EU+ countries further indicated involvement with assessment of ICT at primary/secondary level. However, although Ireland was involved from 2003-2006 in OECD Programme of International Student Assessment (PISA) (at secondary level), there was no involvement in primary education, with five of the 38 countries being involved at both levels during the period of 2001-2007.

The statistics further indicated that only $11 \%$ of grade 4 students (second class, 7-8 years) in Ireland had in 2001 ever used a computer, with a lack of relevant evidence (literature) being available to determine a change in subsequent years (2003-2007), as opposed to $97 \%$ in the UK, 94\% in US, $95 \%$ in France, and $85 \%$ in Denmark (listing a few of the top countries). Ireland had the lowest involvement in this area, with similar results for grade 4 students using computers on a weekly basis with Ireland scoring 9\% (and no subsequent data available for later years), followed with similar statistical reports for Ireland in relation to "information retrieval" in the same age group with Ireland having $7 \%$ in 2001 , as opposed to US $74 \%$, UK $80 \%$, and Sweden with $62 \%$ for same years. However, the statistical evidence for secondary education proved more favourable with results for Ireland indicating children aged 15 years and having used a computer to be $100 \%$ in 2003 and $99 \%$ in 2006 , with UK at $100 \%$, US at $98 \%$, and no further statistics for 2006, and Denmark, Finland, and Germany scoring $100 \%$ consistently for both years. Unfortunately, this was not the case for the use of "computers for collaboration in school work", with relatively low percentages shown for Ireland at 74\%, Spain 89\%, and Japan at $64 \%$ in 2006. In further evidence indicating the 15 years olds involvement with computer use to learn general applications, such as "spread sheets", in 2006, Ireland obtaining $46 \%$ is once again the lowest, with Sweden $48 \%$ and Japan $49 \%$, while Latvia and Hungry gain the highest scores with $84 \%$ and UK scores a modest $76 \%$. Evidence would suggest that while some support in computer use in Ireland is evident at secondary level, this does appear to be limited to word-processing and home use, while at primary level in 2007 at least, the ICT supports in Irish schools would appear to be practically none existent (Pelgrum-Edasmo, 2009).

In a later statistical analysis of European systems and policy, EACEA (2011) indicating in the 32 participant countries in relation to computer use for school-related work as still being relatively low despite increase access to Internet and personal household computers. In 2010, results indicated the UK at $90 \%$, Norway $90 \%$, and Netherlands $99 \%$, with Ireland scoring $55 \%$ at 8 th grade (6th class aged 12 years). The statistics indicate that although ICT is widely promoted as a tool for teaching and learning within other subject areas (promoted by policy), a different picture is portrayed in practice (EACEA, 2011), with $50 \%$ of teachers never requiring students to use computers. These results further indicated the distribution of student/computer ratio in school of children aged 15 years, with statistics indicating a spread of 1.75-2.9 child per computer in Ireland as oppose to 0.5-1.2 child per computer in UK Scotland, and 0.9-1.75 child per computer in UK England; with Ireland having a median of 2.3 children to computer as opposed to UK Scotland 0.75 children to computer, with UK England having 1.75 children to computer. Therefore, the UK countries are averaging 1-1, whereas Ireland has almost 2-1; with other countries, for example, Poland having a median of 4.4 children to 
computer and Turkey's median being 5.6 children to computer, leaving them significantly lower number of computers per capita than either Ireland or the UK.

Statistics further indicate that the majority of head teachers who took part in the international survey identified a major shortage or inadequacy of computers, software, and ICT support, which they felt considerably affected mathematics, science, and literacy instruction for $40 \%$ of students. The survey further indicates the shortfalls in "teacher acquired ICT teaching skills" in initial teacher training. While regulations in only slightly more than $1 / 2$ of the European countries have made ICT a compulsory requirement amongst the knowledge and skills acquired by teachers, all other countries including Ireland give universities and higher education institutions the autonomy to decide whether or not ICT is included and to what extent, with all EU countries except Denmark and Iceland reporting development of qualified teacher's ICT skills in CPD. However, the survey indicated limited participation from teachers in CPD activities that were not compulsory or funded, particularly in areas of mathematics at $51 \%$ and science at $41 \%$ in secondary education and significantly lower levels of $25 \%$ in mathematics and $16 \%$ for science at primary level (European Commission, 2010).

\section{Irish Statistics}

Cosgrove, Perkins, Moran, and Shiel (2011) provided a more positive outlook for Ireland in respect of "digital reading literacy" in the OECD PISA results of 2009 assessing 15 years old in Ireland, and indicating Ireland's participation in PISA since 2000, supporting EU statistics in most areas; although notably excluding the primary sector, the UK, Germany, Finland, and US with statistical evidence showing PISA results as between $98 \%-100 \%$ in previous OECD studies. These results show Ireland with significantly higher than the OECD digital average in comparison to paper-based reading, and in fact being in the top nine countries of those participating in the study. However, when the breakdown is completed over a spread of schools, there is a more comparable average to the EU study of 2000-2006 as indicated above, with Ireland achieving at level 5 an equal $8 \%$ to the OECD average and $12 \%$ in comparison to OECD $17 \%$ at level 2; with Cosgrove et al. (2011) explaining Irelands achievement levels being linked to the type of educational experience and opportunities in schools (school variance). Results in school variance (Cosgrove et al., 2011) portray Ireland at $22 \%$ as considerably lower than the OECD average of $37 \%$ and in fact, the third lowest of the 19 countries which participated in the digital reading assessment.

\section{Results From Studies}

Cosgrove et al. (2011) highlighted in their study an overall pupil-level correlation between digital reading and print reading in Ireland, thus indicating that children who performed well on print reading generally performed well on the digital reading and vice versa. However, Magennis (2011) indicated a negative correlation in the two comparative areas suggesting that children who were good on computers were less likely to be good on pen/paper. In fact, it appeared that as children improve on computer activities, they simultaneously become less adept at pen/paper, with further results of Magennis indicating a positive correlation between children's involvement and performance in the pen/paper activity and computer activity. On closer examination, Magennis (2011) indicated a much stronger positive correlation in respect of the children's involvement/attention and concentration and the positive scores on the computer-based activity in comparison to the pen/paper involvement and pen/paper score, as shown in Figures 1 and 2. 


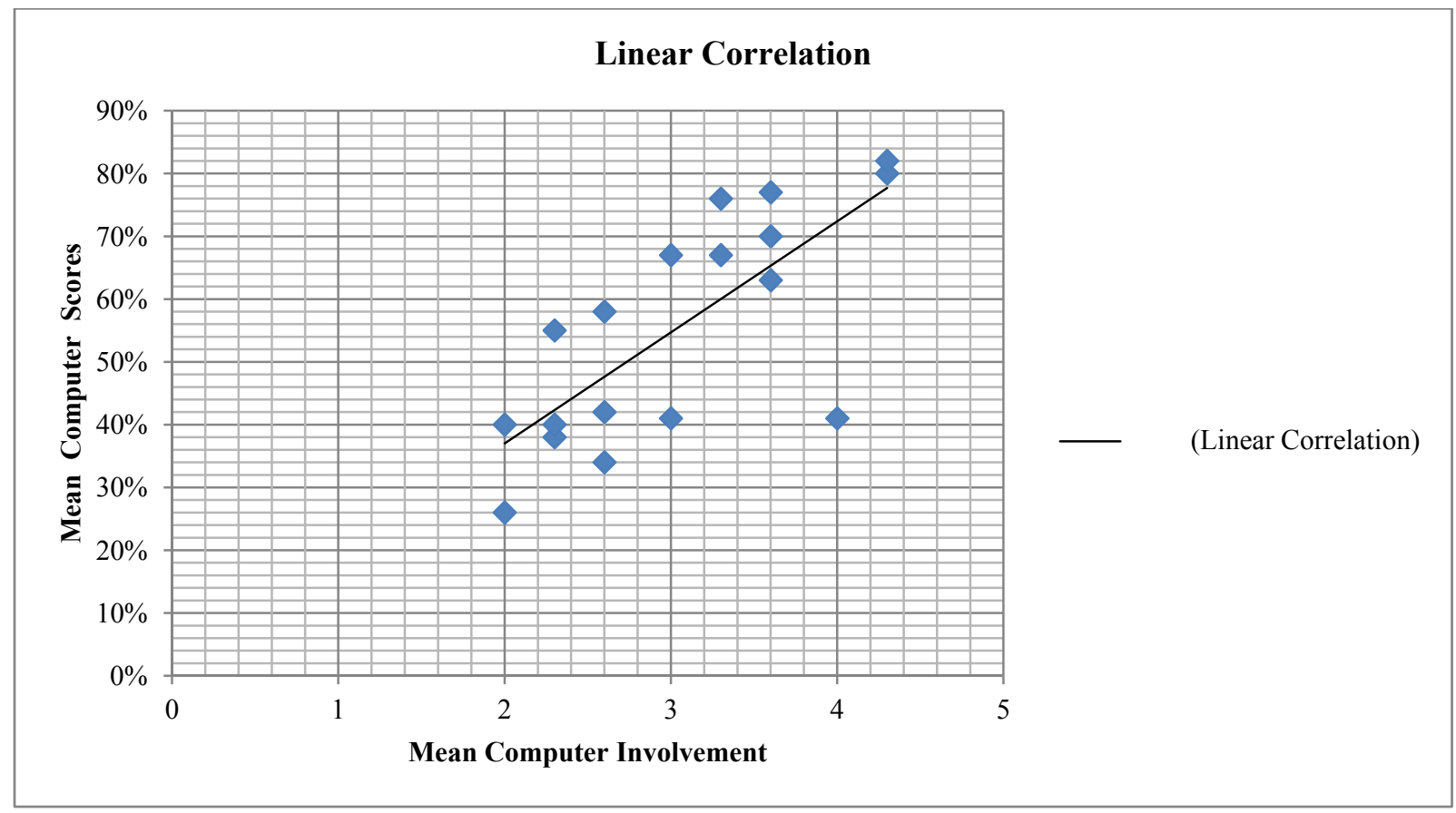

Figure 1. Indicating a strong positive correlation between involvement and score.

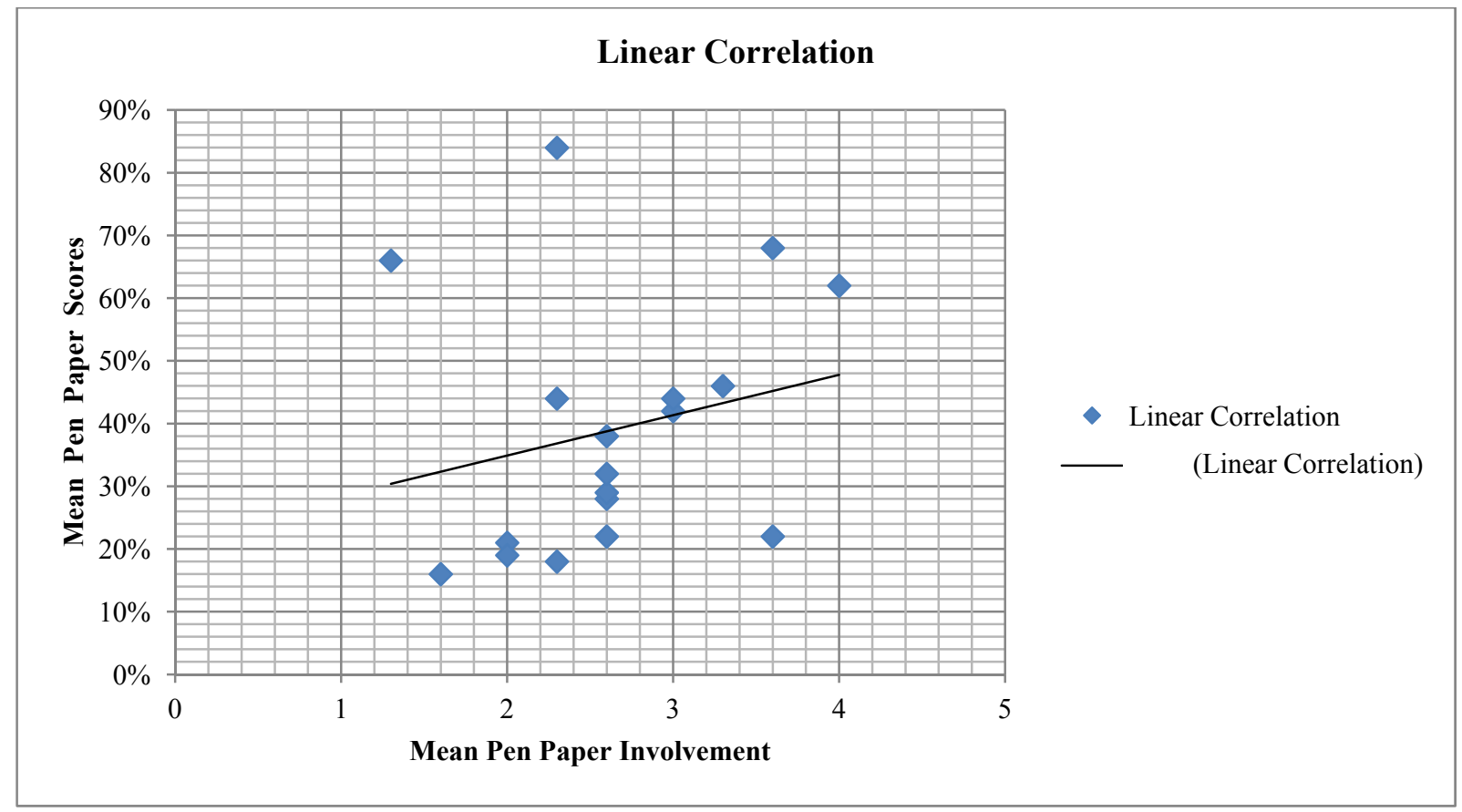

Figure 2. Indicating a positive correlation between pen/paper involvement and score (at a much lesser scale).

It was concluded that there was inevitably more benefit in the positive interaction of the computer-based activity and the emergent conceptual development of the young participants, in particularly holding their interest in the subject area, helping them remain on task and score higher in this activity. Further studies supporting these claims are Madden et al. (2009); Plowman and Stephen (2005); Plowman, Stevenson, McPake, Stephen, and Adey (2011); and Freeman et al. (2010). 


\section{Conclusion}

Throughout this paper, it has been demonstrated that supporting national and international literature shows the benefits of integrating ICT as a suitable resource to enhance the learning experience of young children in areas of the curriculum including literacy; while highlighting the shortfall in relevant literature and policy implementation in Ireland and other EU countries. Supporting results include Bertram and Pascal (1996), Yelland (2001; 2010), Bolstad (2004), BECTA (2008), O'Neill et al. (2008), Plowman and Stephen (2005), and Plowman et al. (2012). Evidence suggests that these limitations stem from a lack of resources and policy implementation (McGarr \& Kearney, 2011; Magennis, 2011; European Commission, 2010), while further indicating a significant lack of suitable ICT involvement in initial teacher training, $\mathrm{CPD}$, teacher competence, and confidence as being a contributing factor in ensuring the successful integration of ICT and retracting from the negative experiences which our digital natives are currently experiencing (Gialamas \& Nikolopoulou, 2010; McDermott, 2011; McGarr \& Kearney, 2011; Magennis, 2011). Currently, policy documents indicate the awareness of both the benefits and shortcomings in this area. However, despite numerous initiatives and intervention schemes, it would appear that in 2013, Ireland and other parts of the EU are still failing to provide the type of support that is needed to ensure these policies are implemented, with particular concern in the area of early and primary education, as evidenced in the statistical data from the European Commission, with Ireland portraying little in the way of diversity and innovation in the teaching styles available to children. In 2001, OECD demonstrated the need for further funding in this area to provide much needed access to computers in school; Punie et al.'s (2008) A Review of the Impact of ICT on Learning suggested changes in the areas of training and resources; and DES (2011b) discussed the need to raise awareness and promote the critical importance of supporting children in areas including ICT. However, in 2013, there is still a significant shortage of suitable ICT equipment available to all of the children in early years and primary education in Ireland (European Commission, 2010; Magennis, 2011), with McDonagh and McGarr (2012) indicating this awareness stems back as far as 1999, when Trench noted it was possible to make a great deal of investment in ICT, without it having a significant gain in the quality of education. It would appear that in 2013, very little has changed. McGarr and McDonagh (2012) presented data indicating the largest obstacle to be overcome in the successful implementation is that of the teacher, suggesting that while most teachers have a positive attitude towards ICT, this attitude will unfortunately provide little assistance in integrating ICT into the classroom. Effective integration of ICT, according to Atkinson and Dias (2001), has more to do with teaching pedagogy than the technology itself, suggesting that by merely resourcing the rooms, the problem will not be resolved, and there is a need for suitable training and support if the changes are to be successful.

Murphy (2011) discussed Ireland in terms of an "insular society", unwilling to move towards innovative methods of teaching, a society which deliberates their own particular circumstance, but remains unwilling to contemplate diversity in its entirety. However, if the children of the future are to be successful in all areas of life, the education system needs to address these issues, and the government needs to implement policy and support CPD and changes in initial teacher training, so that teachers and schools of the future will be able to avail of the resources and funding necessary to support and enhance the skills of digital natives in this ever growing technological world. With an eye to the future, it is intended to complete further research in this area as a comparative study to advance the development in the area of ICT in early education, in an attempt to move forward out of this insular society, with the aim to creating a much more diverse and innovative education 
system helping digital natives to evolve and become successful citizens of the future.

\section{References}

Alliance for Childhood. (2000). Fool's gold: A critical look at computers in childhood. Retrieved February 29, 2013, from http://www.cccs.berkeley.edu/-bh/alliance

Atkinson, J., \& Dias, L. B. (2001). Technology integration: Best practice-Where do teachers stand? International Electronic Journal for Leadership in Learning, 5(11), 1-14.

Aviram, A. (2000). The integration of ICT and education: From computers in the classroom to mindful radical adaptation of education systems to the emerging cyber culture. Journal of Educational Change, 1, 331-352.

Aviram, A., \& Comay, O. (2003). Strategic thinking on ICT and education: Its necessity and basic characteristics. Paper presented at The Havana/Es 2002 conference on ICT and Education.

Aviram, A., \& Talmi, D. (2001). ICT and education-The lacking discourse. Paper presented at The Barcelona Seminar on Geographic's of Educational Change.

Bertram, T., \& Pascal, C. (1996). Evaluating and developing quality in early childhood settings: A professional development programme. Worchester: Amber Publishing.

Bolstad, R. (2004). The role and potential of ICT in early childhood education: A review of New Zealand and international literature. Wellington: Ministry of Education, New Zealand Council for Educational Research.

British Educational Communications and Technology Agency (BECTA). (2008). A review of the evidence on the use of ICT in the early years foundation stage. Coventry: Early Childhood Research Unit, Institute of Education.

Buckingham, D. (2000). After the death of childhood: Growing up in the age of electronic media. Oxford, U.K.: Policy Press.

Cohen, R. (1993). The use of voice synthesizer in the discovery of the written language by young children. Computers and Education, 21(1/2), 25-30.

Cooper, B., \& Brna, P. (2002). Hidden curriculum, hidden feelings: Emotions, relationships and learning with ICT and the whole child. Paper presented at The British Educational Research Association 2002, UK.

Cosgrove, J., Perkins, R., Moran, G., \& Shiel, G. (2011). Digital reading literacy in the OECD Programme for International Student Assessment (PISA 2009): Summary of results for Ireland. Ireland: Educational Research Centre, St Patricks College.

Davis, B. C., \& Shade, D. D. (1999). Integrating technology into the early childhood classroom: The case of literacy learning. Information Technology in Childhood Education, 221-254.

Davis, H., \& Sullivan, O. (2002). Literacy and ICT in the primary classroom: The role of the teacher. In A. Loveless, \& B. Done (Eds.), ICT in the primary school. Buckingham: Open University Press.

Dawes, L., Mercer, N., \& Wegerif, R. (2000). Extending talking and reasoning skills using ICT. In M. Leask, \& J. Meadows (Eds.), Teaching and learning with ICT in the primary school. London, U.K.: Routledge.

Dawson, B. (2008). Use of information communication technology by early career science teachers in Western Australia. International Journal of Science Education, 30(2), 203-219.

Department of Education and Science (DES). (2008a). The ministers strategy group report, investing effectively in ICT in schools: 2008-2013. Dublin: Stationary Office.

DES. (2008b). ICT in schools' inspectorate evaluation studies: Evaluation support and research unit. Dublin: DES.

DES. (2011a). Smart schools - Smart economy (Report of the ICT in Schools Joint Advisory Group to the Minister of Education and Science, Ireland).

DES. (2011b). Literacy and numeracy for learning and life: The national strategy to improve literacy and numeracy among children and young people 2011-2020. Dublin: DES.

Downes, T. (2002). Children's and families use of computers in Australian homes: Contemporary issues in early childhood. Technology Special Issue, 3(2), 182-196.

Educational Audio Visual and Cultural Executive Agency (EACEA). (2011). Key data on learning and innovation through ICT at school in Europe. Brussels: EU.

Eidson, S., \& Simmons, P. E. (1998). Micro-computer simulation graphic and alphanumeric modes: Examining student's process skills and conceptual understanding. Journal of Computers in Mathematics and Science Teaching, 17(1), 21-61.

Elkind, D. (1996). Young children and technology: A cautionary note. Young Children, 51(6), 22-23.

European Commission. (2010). Unlocking the potential of cultural and creative industries. Brussels: EU.

Fatouros, S. C. (1995). Young children using computers: Planning appropriate learning experiences. Australian Journal of Early Childhood, 20(2), 1-6. 
Fletcher-Flynn, C. M., \& Gravatt, B. (1995). The efficacy of computer assisted instruction (CAI): A meta-analysis. Journal of Educational Computing Research, 12, 219-242.

Fomichova, O., \& Fomichova, V. (2000). Computers and the thought-producing self of the young child. British Journal of Educational Technology, 31(3), 213-220.

Freeman, E., Holmes, B., \& Tangrey, B. (2010). ICT for learning: An international perspective on Irish initiative. Dublin, Ireland: Centre for Research in IT in Education, Trinity College.

Gialamas, V., \& Nikolopoulou, K. (2010). In-service \& pre-service early childhood teachers' views and intentions about ICT use in early childhood settings: A comparative study. Computers \& Education, 55(1), 333-341.

Haugland, S. (1999). What role should technology play in young children's learning? Young Children, 54(6), 26-31.

Haugland, S. (2000). Early childhood classrooms in the 21st century: Using computers to maximise learning. Young Children, $55(1), 12-18$.

Hayden, C. (1998). Exclusion from primary school: Children "in need" and children with special needs. Emotional and Behavioural Difficulties, 2(3), 36-44.

Hayden, C., \& Johns, M. (1998). Exclusion or inclusion: Positive strategies for recognising and managing behaviour in schools. Dunstable: Folens.

Hayden, C., \& Martin, T. (1998). Safer cities and exclusion from school. Journal of Youth Studies, 1(3), 315-331.

Healy, J. (1998). Failure to connect: How computers affect our children's minds-for better or worse. New York, N.Y.: Simpn \& Schuster.

Helios. (2006). Helios yearly report 2005-2006. Retrieved from http://www.education-observation.net/helios

Hermans, R., Tondeur, J., Ban Braak, J., \& Vakke, M. (2008). The impact of primary school teachers' educational beliefs on the classroom use of computers. Computers \& Education, 51(2), 1499-1509.

Higgins, S. (2002). ICT and teaching for understanding. Evaluation \& Research in Education, 15(3), 164-171.

Hohmann, C. (1998). Evaluating and selecting software for children. Childcare Information Exchange, 98(9), 60-62.

Howard, S., Dryden, J., \& Johnson, B. (1999). Childhood resilience: Review and critique of literature. Oxford Review of Education, 25(3), 307-323.

Howard, J., Greyrose, E., Kehr, K., Espinosa, M., \& Beckwith, L. (1996). Teacher-facilitated micro-computer activities: Enhancing social play and affect in young children with disabilities. Journal of Special Education Technology, XIII(1), 36-47.

Howard, S. (1998). Wired-up: Young people and the electronic media. London, U.K.: Falmer Press.

Jordan, B. (1999). Technological tools supporting the scaffolding of learning: New Zealand research. Early Childhood Education, 2, 53-66.

Madden, M., Chung, P. W. H., \& Dawson, C. W. (2009). Cartoons beyond clipart: A computer tool for storyboarding and story writing. Computer \& Education, 52, 188-200.

Magennis, M. (2011). The impact of ICT on pre-mathematical concepts in early years children. Belfast: Stranmillis.

Marzanos, R. J. (1998). A theory-based meta-analysis of research on instruction. Retrieved from http://www.mcrel.org

McClain, K., \& Cobb, P. (2001). Supporting students' ability to reason about data. Educational Studies in Mathematics, 45(1), 103-129.

McDermott, E. (2011). ICT as a learning tool in ECE (Presentation for OMEP, Ireland).

McDonagh, A., \& McGarr, O. (2012). Examining the role of the ICT coordinator in Irish post-primary schools: Technology, pedagogy and education. Ireland: University of Limerick.

McGarr, O. (2009). The development of ICT across the curriculum in Irish schools: A historical perspective. Ireland: University of Limerick.

McGarr, O. (2010). Education for sustainable development in technology education in Irish schools: A curriculum analysis. Ireland: University of Limerick.

McGarr, O., \& Kearney, G. (2011). The role of the teaching Principal in promoting ICT use in small primary schools in Ireland. Ireland: University of Limerick.

Moseley, D., Baumfield, V., Elliot, J., Gregson, M., Higgins, S., Miller, J., \& Newton, D. (2005). Frameworks for thinking: A handbook for teaching and learning. Cambridge, U.K.: Cambridge University Press.

Murphy, M. (2011). Making Ireland a caring and equal society. Studies: An Irish Quarterly Review, 100(397), 43-53.

O'Hara, M. (2004). ICT in the early years: Classmates. London, U.K.: Continuum.

O'Neill, B., Hayes, N., \& Downey, S. (2008). Play and technology: A study of ICTs in play activities of Irish children (4-8 and 8-12). Ireland: Dublin Institute of Technology. 
Organization for Economic Cooperation and Development (OECD). (2000). A new economy? The changing role of innovation and information technology in growth. Paris: OECD.

OECD. (2001). Understanding the digital divide. Paris: OECD.

Papert, S. (1996). The children's machine. New York, N.Y.: Basic Books.

Patterson, M. (2004). How can ICT enrich the learning environment in early childhood centres? Computers in N.Z. Schools, 16(1), 25-30.

Pelgrum-Edasmo, W. J. (2009). Indicators on ICT in primary and secondary education. Brussels: EACEA.

Plowman, L., \& Stephen, C. (2003). Information \& communication technology in preschool settings: A review of the literature. International Journal of Early Years Education, 11(3), 223-334.

Plowman, L., \& Stephen, C. (2005). Children, play and computers in preschool education. British Journal of Educational Technology, 36(2), 145-157.

Plowman, L., McPake, J., \& Stephen, C. (2008). Just picking it up? Young children learning with technology at home. Journal of Education, 38(3), 303-319.

Plowman, L., Stevenson, O., McPake, J., Stephen, C., \& Adey, C. (2011). Parents, preschools and learning with technology at home: some implications for policy. Journal of Computer Assisted Learning, 27, 361-371.

Plowman, L., Stevenson, O., Stephen, C., \& McPake, J. (2012). Preschool children's learning with technology at home. Computers \& Education, 59(1), 30-37.

Punie, Y., Zinnbauer, D., \& Cabrera, M. (2008). A review of the impact of ICT on learning. JRC Technical Notes European Commission. IPTS.

Shamir, A., Korat, O., \& Barbi, N. (2008). The effects of CD-ROM storybook reading on low SES kindergarteners' emergent literacy as a function of learning context. Computers in Education, 51, 354-367.

Siraj-Blatchford, J., \& Siraj-Blatchford, I. (2002). Developmentally appropriate technology in early childhood: Video conferencing. Contemporary Issues in Early Childhood: Technology Special Issue, 3(2), 216-225.

Siraj-Blatchford, J., \& Whitebread, D. (2003). Supporting information and communication technology education in early childhood. Buckingham: Open University Press.

Stephen, C. (2005). Researching children's experiences: Approaches and methods. Journal of Early Childhood Research, 3(3), 330-332.

Stephen, C. (2012). Participatory learning in the early years: Research and pedagogy. British Journal of Educational Studies, $10(6)$.

Stephen, C., \& Plowman, L. (2003). A “benign addition?” research on ICT and pre-school children. Journal of Computer-Assisted Learning, 19(2), 149-164.

Stephen, C., \& Plowman, L. (2008). Enhancing learning with ICT in preschool. Early Child Development and Care, 178(6), 637-654.

Stephen, C., Plowman, L., \& McPake, J. (2010). Growing up with technology: Young children learning in a digital world. London, U.K.: Routledge.

Talley, S., Lancy, D. F., \& Lee, T. R. (1997). Children, storybooks and computers. Reading Horizons, 38, 116-128.

U.S. Department of Commerce. (2002). Visions 2020: Transforming education and training throughout advanced technologies. Washington, D.C.: U.S. Department of Commerce. Retrieved February 15, 2013, from http://www.technology.gov

Vekiri, I. (2009). Boys \& girls' ICT beliefs: Do teachers matter? Computers \& Education, 55(11), 16-23.

Weaver, G. C. (2000). An examination of the national educational longitudinal study database to prove the correlation between computer use in school and improvement in test scores. Journal of Science and Technology, 9(2), 121-133.

Wood, C., Pillinger, C., \& Jackson, E. (2009). Understanding the nature and impact of young readers' literacy interests with talking books and during adult reading support. Computer \& Education, 54(8), 190-198.

Yelland, N. (1999). Reconceptualizing schooling with technology for the 21st century. Information Technology in Childhood Education Annual, 39-59.

Yelland, N. (2001). Teaching and learning with information and communication technologies (ICT) for numeracy in the early childhood and primary years of schooling. Canberra: Department of Education, Training and Youth Affairs.

Yelland, N. (2010). Knowledge building with ICT in the early years of schooling. He Kupu: The World, 2(5), 33-44. 